DOI: https://doi.org/10.32839/2304-5809/2020-12-88-31

УДК 657

Мельник Т.Г., Кошолап Я.П.

Київський національний університет імені Тараса Шевченка

\title{
ПРОБЛЕМИ ВИЗНАННЯ І ВІДОБРАЖЕННЯ В ОБЛІКУ ДОХОДІВ ПІДПРИЄМСТВА
}

Анотація. У статті проаналізовано поняття доходу, ключові моменти обліку доходів підприемства, основні проблеми пов'язані з визнанням та обліком доходу підприемства та можливі шляхи їх вирішення. Дохід підприемства - це один з найважливіших критеріїв у його діяльності. Збільшення доходу для підприемства повинно бути пріоритетним завданням. Під час основної діяльності, спрямованої на зростання прибутковості, підприемству слід вжити всіх заходів для максимізації доходу. Важливо правильно аналізувати доходи підприемства, працювати над їх ефективністю та використовувати всі наявні можливості. Для справедливого відображення всіх показників підприемства у фінансовій звітності, дуже важливо відображати дохід у правильній сумі за коректний звітний період. Для цього підприемству також слід вести облік доходів правильно та у відповідності до всіх вимог. Основною метою для коректного обліку та відображення в фінансовій звітності доходів підприемства є можливість користувачів фінансової звітності ознайомитись з правильними основними фрінансовими показниками компанії для фрормування загального бачення стосовно успішності діяльності підприемства.

Ключові слова: дохід, підприемство, прибуток, виручка, коректний період, звіт про фінансові результати (звіт про сукупний дохід).

Melnyk Tetiana, Kosholap Yana Taras Shevchenko National University of Kyiv

\section{PROBLEMS OF INCOME RECOGNITION AND REFLECTION IN ACCOUNTING OF THE ENTERPRISE}

Summary. This article analyses the general concept of income, the key points of income accounting for each enterprise, the main problems associated with the recognition and accounting of the enterprise's income and the main possible ways to solve them. The company's income is one of the most important criteria in its activities. Frankly speaking, revenue is a crucial factor of success of each company. Income from main activities of the company is key indicator of its success. Revenue helps to be profitable for the company, which is the main goal of every business. Increasing income for the company should be a task of first the priority. During the main activity aimed at increasing profitability, the company should take all possible measures to maximize revenue. It is important for each enterprise to properly analyse the company's revenues, work on their efficiency, allocate reserves for efficiency and use all available opportunities. To fairly reflection of all indicators of the enterprise in the financial statements, it is very important to reflect the correct income from all activities for appropriate reporting period. To do this, the company should correctly account income accordingly to all requirements of all regulating accounting laws, regulations and standards. Accounting of revenue is complicated section of accounting for many companies. That is why there are some problems with correct reflection of income in the accounting of the enterprise. Additional control activities are needed in accounting of revenue for most enterprises in order to minimize possible random or special errors in accounting and financial statement in areas related to income. This is especially true about specially made mistakes by people, interested in personal gain. So, control activities are very important to minimize risks of inappropriate reflection of revenue in financial statement. Standards related to accounting of revenue defined main rules for correct recognition and reflection of revenue in company's accounting and then in financial statement. The main aim is possibility of users of financial statements to get acquainted with correct main financial indicators of company.

Keywords: income, enterprise, profit, revenue, statement of financial performance (statement of comprehensive income).

$\Pi$ остановка проблеми. Головною метою діяльності кожного підприемства є максимізація прибутку. Виходячи з цього, одним із найважливіших понять в діяльності підприемства $\varepsilon$ його доходи, які потребують детального аналізу. Доходи підприемства є джерелом його функціонування в теперішньому та майбутньому. Отримання доходу на достатньому рівні сприяе розвитку підприемства та покращення його фрінансового стану. Для власників (акціонерів) підприемств, достатні доходи е гарантіею того, що вони отримають прибуток від діяльності підприемства, що є одніею з їх цілей. Тому розгляд проблем щодо відображення в обліку доходів підприемства $є$ актуальною темою для дослідження.

Аналіз останніх досліджень і публікацій. Поняття «дохід», «дохідність» підприемства, клю- чові моменти при їх обліку, аналізі та контролі завжди знаходилися в центрі уваги багатьох дослідників. Поняття доходу, як економічної категорії, розглядалося в працях Д. Джонса, Дж. Мілля, М. Морхарта, Ф. Найта, А. Сміта, Дж. Хікса. В сфері обліку доходів питання розглядали такі вчені як: Ф.Ф. Бутинець, Я.М. Герасимович, С.Ф. Голов, Л.В. Глушко, В.Г. Лінник, В.В. Полянко, В.Г. Савицька, В.Г. Швець та інші.

Виділення не вирішених раніше частин загальної проблеми. На сьогодні не вирішеними залишаються певні питання щодо визнання в обліку доходів підприемства, особливо щодо визначення коректного періоду для їх відображення.

Мета статті. Головною метою цієї роботи є розгляд проблем визнання і відображення в об- 
ліку та звітності доходів підприемства в умовах евроінтеграції.

Виклад основного матеріалу. Важливу роль в правильності відображення доходів від діяльності підприемства в бухгалтерському обліку та фрінансовій звітності відіграють національні та міжнародні стандарти в сфері обліку та звітності, які регулюють питання визнання, критерії оцінки, основні види доходів підприемства та особливості їх обліку.

Фінансовим результатом діяльності суб'єкта господарювання $є$ отримання економічної вигоди від використання його активів - прибутку (збитку). Із загальної кількості підприемств України (2019 рік - 1941701 одиниц [10]) за видами економічної діяльності 73,6\% - одержали чистий прибуток, 26,4 \% - відповідно збиток у 2019 році [11].

Основним джерелом інформації для користувачів є одна із форм фрінансової звітності - Звіт про фрінансові результати (звіт про сукупний дохід) - Національне положення (стандарт) бухгалтерського обліку 1 «Загальні вимоги до фінансової звітності» (НП(с)БО 1) або Звіт про прибутки та збитки та інший сукупний дохід - Міжнародний стандарт бухгалтерського обліку 1 «Подання фрінансової звітності» (МСБО 1). Елементами цього звіту є доходи та витрати, які мають відповідати критеріям, що встановлюються відповідними стандартами - залежить від того, якими керується підприемство - національні чи міжнародні. Сутність категорії доходи представлено на рис. 1.

Стаття, як елемент фінансової звітності, має відповідати певним критеріям, що визначенні концептуальною основою фрінансової звітності з урахуванням вимог окремих стандартів (нащіональних чи міжнародних) (рис. 2).

Наразі через неправильне застосування та трактування стандартів, а часом не врахування їх вимог, підприемства відповідно припускаються помилок при визнанні доходу.

Відповідно до нащіонального положення (стандарту) бухгалтерського обліку 15 «Дохід» (НП(c)БО 15), доходи підприемства діляться на певні види (рис. 3).

Основним видом доходів для підприемств $є$ доходи від реалізації продукції (товарів, робіт, послуг), що свідчать статистичні дані, які наведені в табл. 1.

Проблеми щодо обліку доходів підприемства пов'язані 3 прийняттям та введенням в дію Міжнародного стандарту фінансової звітності 15 «Дохід від договорів з клієнтами» (МФСЗ 15), в якому змінився підхід та послідовність визнання доходів підприемства.

Послідовність визнання доходів за міжнародними стандартами визначає необхідність слідуванню п'яти крокам, які детально наведені в МСФЗ 15, що свого часу ускладнило розуміння спеціалістами правильності відображення доходів, тому виникли певні труднощі при веденні обліку та складанні фінансової звітності. Проте вирішенням даної проблеми стали детальні роз'яснення Ради 3 міжнародних стандартів бухгалтерського обліку та різноманітні консультації, 3 якими могли ознайомитися всі бажаючі. При впровадженні МСФЗ 15 в підприємств також могли виникнути нові складнощі, адже новий стандарт визначив чіткіші критерії для визначення
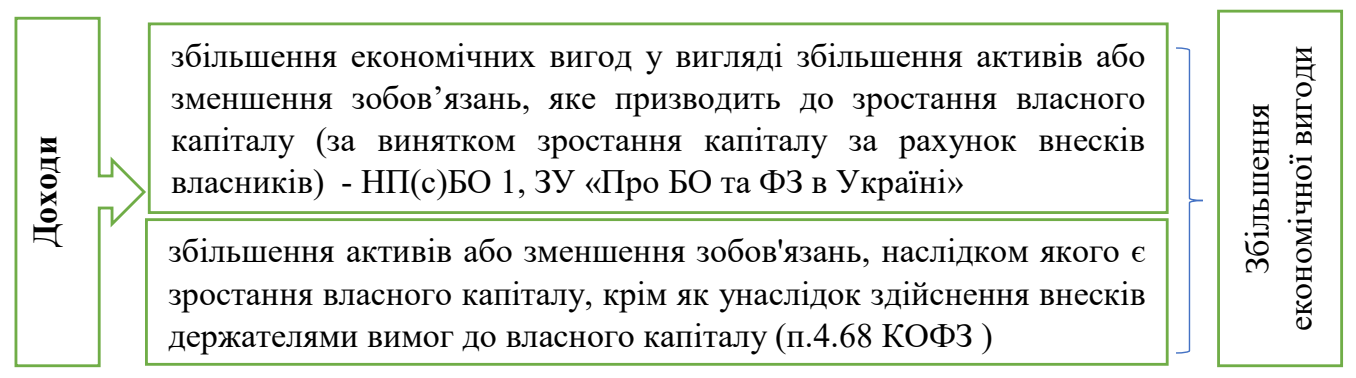

Рис. 1. Сутність категорії доходи

Джерело: систематизовано авторали за [1; 2; 6]

\begin{tabular}{|c|c|}
\hline 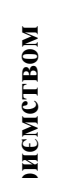 & $\begin{array}{l}\text { під час збільшення активу або зменшення зобов'язання, що зумовлює зростання } \\
\text { власного капіталу (за винятком зростання капіталу за рахунок внесків учасників } \\
\text { підприємства, за умови, що оцінка доходу може бути достовірно визначена } \\
\text { (п.5 НП(с)БО 15) }\end{array}$ \\
\hline 角 & $\begin{array}{l}\text { унаслідок передачі обіцяних товарів або послуг клієнтам у сумі, що відображає } \\
\text { компенсацію, на яку підприємство очікує мати право в обмін на ці товари або } \\
\text { послуги (п.5.4 МСФ3 15) }\end{array}$ \\
\hline$\underset{ }{\mathbb{E}}$ & $\begin{array}{l}\text { одночасно } 3 \text { первісним визнанням активу чи збільшенням балансової вартості } \\
\text { активу; або припиненням визнання зобов'язання чи зменшенням балансової } \\
\text { вартості зобов’язання (п.5.4 Концептуальної основи ФЗ) }\end{array}$ \\
\hline
\end{tabular}

Рис. 2. Критерії визнання доходу підприемством

Джерело: узагальнено авторами за [3; 4; 6] 


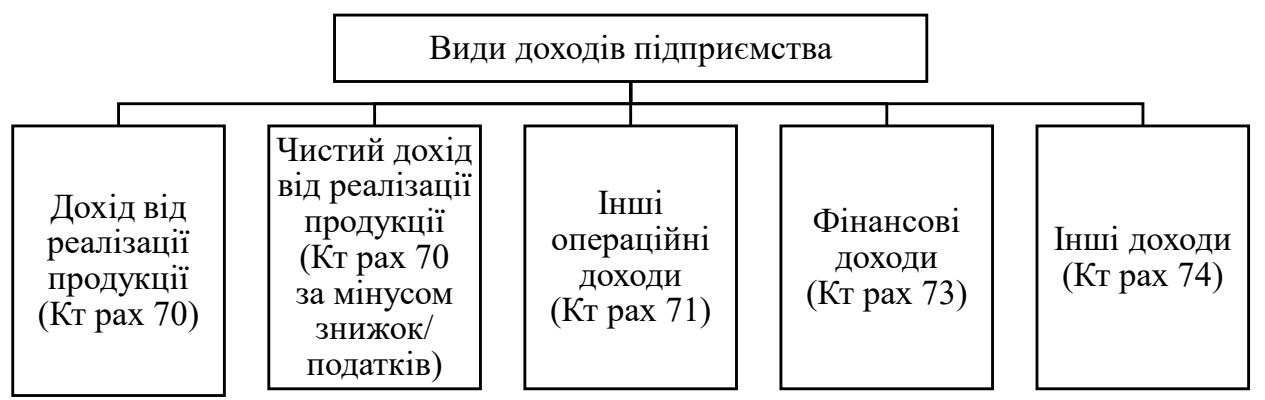

Рис. 3. Види доходів підприемства за НП(с)БО 15

Джерело: узагальнено авторами за даними [3]

Види доходів підприемств у 2019 році (млн. грн)

Таблиця 1

\begin{tabular}{|c|c|c|c|}
\hline $\begin{array}{c}\text { Чистий дохід від реалізації } \\
\text { продукції та чисті зароблені } \\
\text { страхові премії / Net income } \\
\text { from the sold products and net } \\
\text { earned insurance premiums }\end{array}$ & $\begin{array}{c}\text { Інші операційні } \\
\text { доходи / Other } \\
\text { operational income }\end{array}$ & $\begin{array}{c}\text { Інші доходи / } \\
\text { Other income }\end{array}$ & $\begin{array}{c}\text { Разом чисті доходи / } \\
\text { Total revenue }\end{array}$ \\
\hline 9659409,7 & 758691,1 & 457305,8 & 10876425,7 \\
\hline
\end{tabular}

Джерело: витяг із [12]

доходів. Тому підприемствам необхідно для вирішення проблемних моментів, переглянути договори 3 покупцями 3 метою конкретнішого тлумачення зобов'язань за контрактом. Також в певних випадках підприемства могли передивитись облікову політику з метою відображення всіх змін міжнародних стандартів. В загальному основною проблемою МСФЗ 15 є те, що міжнародні стандарти спрямовуються на поступове зближення правил ведення обліку та складання фінансової звітності для всіх країн з метою стандартизації вимог та систем обліку в загальному. При цьому не враховуються національні особливості кожної конкретної країни, України в тому числі. Проте така ситуація пов'язана 3 процесами глобалізації в усьому світі та евроінтеграції нашої країни.

Однією 3 найбільш поширених помилок при відображенні доходів підприемства в бухгалтерському обліку та звітності можна вважати визнання їх в некоректному періоді. Оскільки процес отримання необхідних документів для відображення доходів в обліку може затягуватися в залежності від різноманітних обставин, іноді виникають ситуації, коли звітний період закритий і певна частина доходів відображається в наступному періоді. Так само можлива ситуація неправильного визначення дати визнання доходів згідно з документами і відображення доходів в попередньому / наступному періоді, коли потрібно було відобразити в іншому. Надалі таке відображення впливає на розкриття доходів в Звіті про прибутки та збитки та інший сукупний дохід, що може вводити в оману користувачів фрінансової звітності.

Звіт про прибутки та збитки та інший сукупний дохід - це основне джерело інформації про фінансові результати суб'єкта господарювання за звітний період (рис. 4) [6].

Коректним періодом для складання фрінансової звітності вважається календарний рік, за який складена така звітність. Для поточного бухгалтерського обліку коректним періодом є місяць, до якого належать відображені бухгалтерські операції.

Згідно $з$ п. 8 НП(с)БО 15: «дохід від реалізації продукції визнаеться при умові, що покупцеві були передані ризики й вигоди, пов'язані з правом власності на продукцію, підприемство не має контролю та здатності управляти реалізованою продукцією, сума виручки може бути достовірно визначена, $є$ впевненість, що за результатом операції відбудеться зростання економічних вигід підприемства» [3]. Відповідно до п. 31 МСФЗ 15: «суб'єкт господарювання визнає дохід, коли (або в міру того, як) суб'єкт господарювання задовольняе зобов'язання щодо виконання, передаючи обіцяний товар або послугу (тобто актив) клієнтові. Актив передається, коли (або в міру того, як) кліент отримуе контроль над таким активом» [5].

Важливим моментом є те, що передача ризиків і вигод, пов'язаних з правом власності на реалізовану продукцію, відбувається згідно з вимогами Incoterms, які зазначаються в договорах або власне в конкретних специфікаціях до договорів. Умови Incoterms конкретно визначають місця передачі ризиків і вигід на реалізовану продукцію. В 2020 році було переглянуто та уточнено основні види Incoterms [8; 13]:

- вилучено позиції EXW, FAS і DDP;

- замість умов DDP доповнено двома новими: DTP (доставка на терміналі з оплатою мита) i DPP (доставка до місця з оплатою мита);

- уведено нову умову поставки CNI (вартість і страхування).

Трактування в міжнародній практищі умов поставок за різними редакціями правил інтерпретації термінів комерційних у договорах перевезення і транспортно-експедиторських договорах, в деякій мірі відрізняеться від трактування цих самих термінів у міжнародних договорах купівлі-продажу. «У результаті існуе досить високий ступінь ризику виникнення збитків учасників зовнішньоторговельної угоди через підміну понять умов по- 


\begin{tabular}{|c|}
\hline \multicolumn{2}{|c|}{ Звітний період } \\
\hline $\begin{array}{c}\text { Для складання фінансової звітності - } \\
\text { календарний рік }\end{array}$ \\
\hline Відповідність якісним характеристикам та дотримання принципів формування \\
фінансової звітності підприємством \\
\hline
\end{tabular}

Рис. 4. Визначення звітного періоду для підприемства

Джерело: складено авторами за $[1 ; 2 ; 6]$

ставки на службові терміни, які використовуються при транспортному експедируванні» [13].

Для відображення доходів від реалізації продукції в правильному періоді підприемству необхідно керуватися саме вимогами щодо передачі ризиків і вигід покупцеві продукції. МСФЗ 15 не встановлює конкретних правил визнання та ощінки доходу. Він містить набір принципів для прийняття підприемством самостійних рішень [7].

Здійснення помилки при визнанні доходів підприємства, а саме відображенні їх в некоректному періоді призводить до завищення або заниження доходів, відображених у фрінансовій звітності підприемства. Прикладом завищення доходів підприємства є ситуація, за якої дохід, який насправді належить до січня наступного року, визначаеться в грудні звітного року. Умовна ситуація - підприемство отримало підписані документи від клієнта на суму 5 млн. грн., за якими датою переходу прав власності на вироблений товар клієнту є дата фрізичного отримання товарів кліентом X, що було відображено у накладній як 2 січня 2021 року. Проте наше підприемство провело дохід від контрагента Х в грудні звітного 2020 року. Така помилка призводить до завищення статті Звіту про прибутки і збитки «Чистий дохід від реалізащії родукції (товарів, робіт, послуг)» на 5 млн.грн. Прикладом заниження доходів підприемства є зворотня ситуація - доходи, які мали б бути визнані в грудні звітного року, визнаються в січні наступного року.

Також існуе ризик того, що фрінансовий відділ підприємств або конкретні особи спеціально визнаватимуть доходи від діяльності в неправильному періоді, ставлячи за мету свої власні вигоди. Випадки спеціального завищення доходів підприємства є вигідні особам, які складають фрінансову звітність, якщо від фінансового показника доходів або прибутків підприємства залежать їх власні матеріальні блага, тобто чим вищим буде дохід підприємства, а власне і прибуток, тим вищу винагороду отримають дані особи. Ціллю для заниження доходів звітного періоду може бути необхідність у заниженні прибутку підприємства для дотримання вимог з метою отримання кредитування від банків або кредиторів.

Як зазначає Глушко Л.В.: «Одним з найважливіших показників діяльності підприемства $є$ дохід, тому надання повної, правдивої та неупередженої інформації про доходи є дуже важливим для прийняття управлінських рішень» [9, с. 2].
Визнання доходів, відображення витрат та фрінансових результатів в бухгалтерському обліку може впливати на прийняття управлінських рішень користувачами фінансової звітності. Викривлення даних в обліку та звітності може мати негативні наслідки для користувачів. В зв'язку з наявними ризиками, власники підприємства навіть без законодавчих вимог, звертаються до аудиторських послуг з метою виявлення помилок при складанні фінансової звітності та веденні бухгалтерського обліку. Визнання доходів та їх відображення в бухгалтерському обліку та звітності вважається зоною підвищеного ризику, тому при проведенні аудиту, для цієї ділянки застосовуються спеціальні процедури, здатні виявити випадки ненавмисних помилок, шахрайства та маніпуляцій 3 даними. Однією із процедур є власне перевірка правильності визнання доходів підприемства.

Таким чином, основними шляхами вирішення проблем щодо визнання доходів в некоректному періоді є:

- залучення кваліфікованих спеціалістів з відповідним рівнем професійної підготовки для ведення обліку та складання фінансової звітності, особливо на ділянці доходів підприемства;

- проведення професійних курсів, тренінгів з підвищення профресійності власних кадрів, які залучаються до обліку та підготовки звітності;

- в разі необхідності отримання індивідуальних консультацій із залученням зовнішніх радників щодо питань 3 визнання та відображення в обліку доходів підприемства;

- створення відділу внутрішнього аудиту або створення посади внутрішнього аудитора 3 метою внутрішнього контролю за діяльністю підприемства;

- проведення зовнішнього аудиту, в разі вимог законодавства або просто необхідності для покращення розуміння проблем 3 відображенням доходів на підприемстві.

Висновки і пропозиції. Отже, облік доходів підприемства є ділянкою підвищеного ризику, особливо в умовах евроінтеграцї нашої країни та оновлення вимог міжнародних стандартів. Існує можливість для маніпуляції 3 даними щодо доходів підприемства з метою пошуку власної вигоди, а також існуе ймовірність випадкових помилок при веденні обліку та складання звітності відповідальними особами. Необхідно щоб відображенням операцій пов'язаних 3 доходами підприємства в бухгалтерському обліку 
та фрінансовій звітності підприємства займалися кваліфріковані працівники, які мають необхідні знання та постійно їх поновлюють паралельно 3 поновленням вимог, правил в стандартах, що регулюють сфреру обліку. Крім того, для зниження рівня ризику виникнення помилок або шахрайства необхідно контролювати облік шляхом введення додаткових контрольних процедур всередині підприемства власниками (акціонерами), таких як: організація відділу внутрішнього аудиту чи призначення окремої посади 3 внутрішнього контролінгу на підприемстві або залучення сторонніх спеціалістів, які б охопили ділянки доходів підприемства.

\section{Список літератури:}

1. Закон України «Про бухгалтерський облік та фрінансову звітність в Україні» від 16.07.1999 № 996-14 / Верховна Рада України. URL: https://zakon.rada.gov.ua/ (дата звернення: 22.10.2020).

2. Національне положення (стандарт) бухгалтерського обліку 1 «Загальні вимоги до фрінансової звітності», затверджене наказом Міністерства фрінансів України від 07.02.2013 № 73. URL: https://zakon.rada.gov.ua/ (дата звернення: 06.12.2020).

3. Національне Положення (стандарт) бухгалтерського обліку 15 «Дохід», затверджене наказом Міністерства фінансів України від 29.11.1999 № 290. URL: https://zakon.rada.gov.ua/ (дата звернення: 22.10.2020).

4. Міжнародний стандарт бухгалтерського обліку 1 «Подання фінансової звітності» виданий Радою з Міжнародних стандартів бухгалтерського обіліку. URL: https://mof.gov.ua/ (дата звернення: 06.12.2020).

5. Міжнародний стандарт фінансової звітності 15 «Дохід від договорів 3 кліентами», виданий Радою з Міжнародних стандартів бухгалтерського обіліку. URL: https://mof.gov.ua/ (дата звернення: 15.11.2020).

6. Концептуальна основа фрінансової звітності, видана Радою з Міжнародних стандартів бухгалтерського обліку. URL: https://zakon.rada.gov.ua/ (дата звернення: 06.12.2020).

7. Войтенко Тетяна. Визнання доходу за МСФ3 15: ключові моменти. Бухгалтер 911. URL: https://buhgalter911.com/ uk/news/news-1046534.html (дата звернення: 08.11.2020).

8. Інкотермс 2020. Офіційний сайт International chamber of commerce. URL: https://iccwbo.org/resources-forbusiness/incoterms-rules/incoterms-2020/ (дата звернення: 08.11.2020).

9. Глушко Л.В. Особливості обліку доходів підприемства. Modern directions of theoretical and applied researches. 15-22 March 2016. URL: https://www.sworld.com.ua/konfer42/81.pdf (дата звернення: 08.11.2020).

10. Кількість суб’єктів господарювання за видами економічної діяльності у 2010-2019 роках. Офіційний сайт Державної служби статистики. URL: http://ukrstat.gov.ua/ (дата звернення: 06.12.2020).

11. Чистий прибуток (збиток) підприемств за видами економічної діяльності з розподілом на великі, середні, малі та мікропідприемства за 2010-2019 роки. Офіційний сайт Державної служби статистики. URL: http://www.ukrstat.gov.ua/ (дата звернення: 06.12.2020).

12. Формування чистого прибутку (збитку) підприемств за видами економічної діяльності у 2019 році. Офіційний сайт Державної служби статистики. URL: http://www.ukrstat.gov.ua/ (дата звернення: 06.12.2020).

13. Трусов Олександр. Інкотермс 2020: особливості можливого застосування. Bicник. 13.11.2019. URL: http://www.visnuk.com.ua/ (дата звернення: 06.12.2020).

\section{References:}

1. Law of Ukraine on the accounting and financial reporting in Ukraine № 996-14 (1999, July 16). Verkhovna Rada of Ukraine. Available at: https://zakon.rada.gov.ual

2. National Accounting Regulation (Standard) 1 "General Financial Reporting Requirements". Order of Ministry of Finance of Ukraine № 73 (2013, February 7). Available at: https://zakon.rada.gov.ua/

3. National Accounting Regulation (Standard) 15 "Income". Order of Ministry of Finance of Ukraine № 290 (1999, November 29). Available at: https://zakon.rada.gov.ua/

4. International Accounting Standard 1 "Presentation of Financial Statements". International Accounting Standards Board. Available at: https://mof.gov.ua/

5. International Financial Reporting Standard 15 "Income from Contracts with Customers". International Accounting Standards Board. Available at: https://mof.gov.ua/

6. Conceptual framework of financial reporting. International Accounting Standards Board. Available at: https://zakon.rada.gov.ua/

7. Voitenko T. Vyznania dokhodu za MSFZ 15: kliuchovi momenty [Recognition of income under IFRS 15: key points]. Bukhalter 911 [Accountant 911] (electronic journal). Available at: https://buhgalter911.com/uk/news/ news-1046534.html

8. Inkoterms 2020 [Incoterms 2020]. Official site of International chamber of commerce. Available at: https:/iccwbo.org/ resources-for-business/incoterms-rules/incoterms-2020/

9. Hlushko L.V. Osoblyvosti obliku dokhodiv pidpryiemstva [Features of accounting of companie's income]. Modern directions of theoretical and applied researches. Available at: https://www.sworld.com.ua/konfer42/81.pdf

10. Kilkist subiektiv hospodariuvania za vydamy economichnoi diialnosti u 2010-2019 rokakh [Number of business entities by type of economic activity in 2010-2019]. Official site of State statistics service. Available at: http://ukrstat.gov.ua/

11. Chystyi prybutok (zbytok) pidpryiemstv za vydamy economichnoi diialnosti z rozpodilom na velyki, seredni, mali ta mikropidpryiemstva za 2010-2019 roky [Net profit (loss) of enitites by type of economic activity with distribution on large, medium, small and micro enterprises in 2010-2019]. Official site of State statistics service. Available at: http://ukrstat.gov.ua/

12. Formuvania chystoho prybutku (zbytku) pidpryiemstv za vydamy economichnoi diialnosti u 2019 rotsi [Formation of net profit (loss) of enterprises by type of economic activity in 2019]. Official site of State statistics service. Available at: http://ukrstat.gov.ua/

13. Trusov O. Inkoterms 2020: osoblyvosti mozhlyvogo zastosuvania [Incoterms 2020: features of possible application]. Visnyk [Herald]. Available at http://www.visnuk.com.ua/ 